\title{
A Ming-kori katonai víváselmélet leírása és elemzése a Jixiao Xinshu víváselméleti értekezései alapján
}

\begin{abstract}
A híres Ming-kori (1368-1644) tábornok, Qi Jiguang 戚繼光 (1528-1588) 1584-ben jelentette meg ${ }^{1}$ átfogó katonai kézikönyvét, a Jixiao Xinshut ${ }^{2}$ 紀效 新書 [Új értekezés a katonai hatékonyságról].Qi műve több szempontból is rendkívüli jelentőségü: egyrészt átfogó, enciklopédikus, a hadviselés minden aspektusát érintő jellegével mintául szolgált a későbbi Ming-kori katonai kézikönyvek szerzőinek. Másrészt a Jixiao Xinshu tartalmazza több harcmüvészeti rendszer leírását is, amelyeket Qi katonai felhasználásra alkalmasnak talált, és ezért oktatásukat a kiképzés fontos részének tartotta. A Jixiao Xinshu a kínai harcmüvészeti rendszerek egyik legkorábbi írott forrásának tekinthető, hadtörténeti és harcmüvészet-történeti jelentőségét azonban tovább növeli, hogy a legrégebbi olyan kínai művek közé tartozik, amelyek - a régi kínai szövegek között egyébként is ritkaságszámba menő - víváselméleti értekezéseket tartalmaznak. ${ }^{3}$
\end{abstract}

A Jixiao Xinshuban található víváselméleti szövegek ritka lehetőséget kínálnak arra, hogy megtudjuk, a Ming-kori katonatisztek hogyan gondolkodtak a hatékony fegyveres közelharcról, és hogy melyek voltak azok a taktikai aspektusok, amelyeket a legfontosabbnak tartottak a hatékony hadviselés szempontjából. A víváselméleti értekezések elemzésével egyúttal képet alkothatunk a harcmüvészetek Ming-kori elméleti megközelítéséről is. Jelen tanulmány a források rövid bemutatását követően prezentál egy értelmezési keretrendszert, amely lehetővé teszi történelmi víváselméleti rendszerek struktu-

Az 1584-ben kiadott mủ valójában a Jixiao Xinshu második, újraszerkesztett, bővített kiadása, amelyet 14 fejezetes kiadásnak is neveznek. Qi müvének első kiadása kb. 1561-ben jelent meg, és 18 fejezetből állt, ám tartalmilag szegényebb volt.

Qi 1782.

Jelenlegi ismereteink szerint csak Yu Dayou 命大猷 Jian Jing 劍經 [Értekezés a kardról] címủ műve korábbi keletkezésü, Yu értekezése azonban, teljes egészében átemelve, a Jixiao Xinshu szerves részét képezi, ld. A forrásokról szakaszt. 
rált leírását és elemzését a sokszor nehezen értelmezhető, ${ }^{4}$ szerkesztetlen forrásszövegekből kivont információk alapján. Ezt követően, a fenti rendszerbe illesztve, részletesen bemutatja a Jixiao Xinshu értekezéseiben leírt víváselméleti rendszer tulajdonságait és taktikai szemléletmódját.

\section{A víváselméletről}

Egy harcmüvészeti rendszer elméleti háttere stratégia céljain és taktikai megfontolásain keresztül írható le, fegyveres rendszer esetén ezt nevezzük az adott harcmüvészet víváselméletének. A víváselmélet azoknak a stratégiai céloknak (pl. az ellenfél megölése, lefegyverzése stb.) és taktikai szemléletmódnak, döntéseknek az összessége, amelyek egy adott harcmüvészeti rendszerre jellemzőek, és amelyek keretet adnak a rendszerbe foglalt technikák müködéséhez. Guy Windsor a történelmi harcmüvészetek kutatásához írt kézikönyvében a víváselmélet fogalmát a következőképpen határozza meg: ,a víváselmélet egy intellektuális, absztrakt struktúra, amelyet a vívók használnak a múvészetük leírására, meghatározására és magyarázatára". ${ }^{5}$ A Ming-kori katonai kézikönyvek vívókönyvei többségükben nem tartalmaznak külön, az elméletet tárgyaló részeket, víváselméleti struktúrájuk legfeljebb a technikai leírásokból következtethetö ki. A Jixiao Xinshu 10. és 12. fejezetei azonban meglehetősen nagy terjedelmü, kifejezetten általános víváselméleti alapelveket leíró részleteket foglalnak magukba, amelyek különböző fegyvernemekkel egyaránt használhatók. Tekintve hogy ezek az elméleti részek megelőzik a fejezetek konkrét harcművészeti technikai leírásait, feltételezhetjük, hogy ezek adják azt az egységes víváselméleti keretrendszert, amely a müben szereplö összes harcmủvészeti rendszer elméleti háttereként alkalmazható.

\section{A forrásokról}

A Jixiao Xinshu víváselméleti értekezéseiben az egyes fegyvernemek víváselméleti háttere nem különül el egymástól. Az értekezések univerzális vívói irányelveket fogalmaznak meg, amelyek számos fegyvernemmel egyaránt

\footnotetext{
4 A történelmi harcmüvészeti források értelmezésének és interpretálásának nehézségeiröl ld. Clements 2016; Burkart 2016.

5 Windsor 2018: 34.
} 
használhatók, a szövegek csak az egészen hosszú, pikaméretủ szálfegyvereket kezelik külön kategóriaként. A Ming-kori katonai víváselmélet legfontosabb forrásait a Jixiao Xinshu 10. és 12. fejezetei tartalmazzák. A 10. fejezet a Chang bing duan yong shuopian 長兵短用說篇 [A hosszú fegyverek rövid használatának magyarázata] címet viseli, és általános víváselméleti irányelveket fogalmaz meg a 2 méternél hosszabb fegyverek, elsősorban a pika és a lándzsa használatával kapcsolatban. ${ }^{6}$ A 12 . fejezet címe Duan bing chang yong shuo 短兵長用說 [A rövid fegyverek hosszú használatának magyarázata]. Ez utóbbi fejezet egyrészt általános elméleti alapelveket fogalmaz meg olyan harci helyzetekre, amelyekben 2 méternél rövidebb fegyverrel harcolunk egy jóval hosszabb fegyver, például pika ellen, másrészt teljes egészében magába foglalja Yu Dayou 俞大猷 (1503-1579) Jian Jing ${ }^{7}$ 劍經 [Értekezés a kardról] címü művét.

A Jian Jing tartalmazza a legátfogóbb ismert Ming-kori víváselméleti rendszert, de az elméletivel azonos terjedelemben tárgyal gyakorlati tanításokat, vívómeneteket ${ }^{8}$ is. Az értekezés - nevével ellentétben - elsősorban botvívó technikákat tartalmaz, de koncepciója szerint a bottal elsajátított víváselméleti rendszer egyformán alkalmazható kardvívás és más szálfegyverek használata során is. Szerzője, Yu Dayou tábornok Qi Jiguang kortársa volt, és hozzá hasonlóan részt vett a wokou 倭寇 kalózok elleni hadjáratokban. Yu élete során számos harcmúvészeti irányzatot tanulmányozott, tudását pedig a Jian Jingben foglalta össze. A Jian Jinget azonban nem önálló müként, hanem egy nagyobb munka, a Zhengqi Tang $J i$ 正氣堂集 [Összegyüjtött írások az éltető energiáról] fejezeteként adta közre. A mü többi része főként belső alkímiai koncepciókkal, gyakorlatokkal foglalkozik, ezek jelen témánkhoz nem kapcsolódnak.

A Jian Jing felépítése a mai olvasó számára meglehetősen következetlen benyomást kelt. ${ }^{9}$ A szöveg elöször saját víváselméleti koncepcióit és egyéb harcmüvészeti tanításait verses formában összefoglaló, úgynevezett emlékeztető versikéket közöl (zong juege 總訣歌), amelyek a könnyebb memorizálást segítik. A verses összefoglalók sorát egy-egy gyakorló menet leírása (xibu fa 習步法) szakítja meg. Ezt követi az egyes támadástípusok tételes felsorolása

6 Továbbá a szerző a hosszú fegyverek kategóriájába sorolja az íjat és a tüzfegyvereket is (Qi 1782: 10. fejezet).

Yu 1782.

Egymást követő, egymásra épülő mozdulatok, technikák sorozata.

Kennedy-Guo 2005: 128-130. 
(zong bumu 總步目), amely azonban kihagy a felsorolásból számos, a későbbiekben említésre kerülő támadástípust. A Jian Jing utolsó, a mü terjedelmének legnagyobb részét kitevő szekciója 154 különálló bekezdésbe rendezve tartalmazza Yu vívórendszerének elméleti tanait, valamint számos konkrét, párviadal során tipikusan bekövetkező helyzet leírását, vívómeneteket, lépésről lépésre levezetett instrukciókkal. A bekezdések tematikai és tipológiai sorrendje teljes mértékben esetleges és véletlenszerü. Alkalmanként egy-egy technika vagy víváselméleti probléma témája köré több bekezdés is csoportosul, ezek kapcsolódását azonban nem jelzi a szöveg. ${ }^{10}$ Az értekezés struktúrája (vagy annak hiánya) azt a benyomást kelti, mintha a szerző minden alkalommal, amikor eszébe jutott egy-egy újabb elméleti koncepció vagy vívói helyzet megoldása, ötletszerüen hozzáírta volna gondolatait a meglévő munkához, mellőzve mindenfajta szerkesztési elvet. A szöveg közé ékelve található három egyszerü diagram, amelyek a vívórendszer legalapvetőbb elméleti koncepcióinak a megértését igyekeznek megkönnyíteni. A Jian Jing eredetiből szó szerint átemelt szövegét a Jixiao Xinshu 12. fejezetében 14 kép követi, amelyek illusztrálják a Yu Dayou által leírt legfontosabb technikákat és vívói helyzeteket. Ezeket az illusztrációkat Qi Jiguang mellékelte a vívókönyvhöz, annak könnyebb értelmezhetősége érdekében.

A Jian Jing egy rendkívül gazdag víváselméleti és gyakorlati harcmüvészeti forrás, komplex elméleti koncepciókkal és átgondolt vívórendszerrel, értelmezését azonban nagyban megnehezíti szerkesztetlensége, a mai olvasó számára alapvetően elvárt tematikus és logikus struktúra hiánya. Ez utóbbi különösen szembetünővé válik, ha a szöveget összevetjük az azt közreadó mü, a Jixiao Xinshu átgondolt és logikus felépítésével. A Jian Jingben leírt vívórendszer azonban mindent tartalmaz, ami egy teljes értékü harcmüvészeti rendszertől elvárható, az alapvető testtartással és a fegyver helyes tartásával kapcsolatos instrukcióktól kezdve, támadási és védekezési technikák leírásán át egy komplex víváselméleti rendszerig, amely a vívás majdnem minden aspektusára kiterjed. Átfogó elemzése rendkívül alapos képet ad a Mingkori fegyveres vívás egy bizonyos, a hadsereg szempontjából is hatékonynak tekintett, ugyanakkor komplexitásában a katonai felhasználás elvárásain túlmutató megközelítéséről.

10 Néhány esetben olvasható egy-egy hivatkozás az előző bekezdés tartalmára, ezek előfordulása azonban inkább kivétel- és nem szabályszerü. 


\section{Egy szerkesztett mủ elemzésének problémái}

Fontos, hogy felhívjuk a figyelmet a forrásszövegek elemzésével kapcsolatos egyik nagy kérdésre: kezelhetjük-e a Jixiao Xinshu 10. és 12. fejezetének elején leírt víváselméleti tanításokat és a Yu Dayoutól a 12. fejezetben szó szerint idézett Jian Jinget egy nagy közös víváselméleti rendszerként? Vitathatatlan tény, hogy Yu víváselméleti értekezése egy önálló és teljes értékű vívórendszert tartalmaz, amely nem szorul kiegészítésre. Ugyanakkor Yu munkájával nem kifejezetten a katonai felhasználhatóságot célozta: a Jian Jing egy gyakorló harcművészeknek - legyenek bár katonák vagy civilek, kezdők vagy haladók - szóló, komplex víváselméleti koncepciókat tartalmazó rendszer. A benne foglalt elméleti koncepciók lényegét egy, a vívásban járatos kiképzőtiszt ugyan meg tudja tanítani a katonáknak a kiképzés során, ám a leírt technikák jelentős része túl összetett a harctéri alkalmazáshoz vagy akár ahhoz, hogy egy a fegyveres harcban teljesen járatlan újonc értelmezni tudja őket.

Ezzel szemben a Jixiao Xinshu két eredeti víváselméleti értekezése rövid, lényegre törő, és csak két specifikus, aszimmetrikus vívói helyzet elméletét tárgyalja, név szerint: a hosszú fegyverekkel való harcot rövid fegyverek ellen és a rövid fegyverekkel való harcot hosszú fegyverek ellen. Ezek a leírások nem tartalmaznak komplex víváselméleti koncepciókat, és nem elegendőek ahhoz, hogy valaki ezek segítségével sajátítsa el a vívás múvészetét, ugyanakkor egyszerü, könnyen begyakorolható válaszokat kínálnak a harcmezőn gyakran előforduló problémákra. A Jixiao Xinshu víváselméleti értekezései kifejezetten a katonai felhasználást célozzák, ugyanakkor hiányosak, nagyon specifikusak, nem tartalmaznak komolyabb víváselméleti koncepciókat. A müvet összeállító Qi Jiguang szándéka következtetésünk szerint az volt, hogy a Jixiao Xinshu víváselméleti magjaként közreadja Yu rendszerét, és ezt kiegészítse bizonyos elemekkel, amelyek a harctéri felhasználás szempontjából kulcsfontosságúak, de hiányoznak a Jian Jingbőll. ${ }^{11}$ A több szövegből összeálló egységes víváselméleti rendszer koncepciójának elmélete mellett szól az a tény is, hogy Qi a 12. fejezet elején található értekezésben, egy technika leírásánál,

11 Ezek az elemek a fegyverek méretét tekintve aszimmetrikus harci szituációk kezelését szolgáló víváselméleti koncepciók. A Yu által leírt vívórendszer elméleti háttere és technikái a nagyjából hasonló méretü fegyverekkel vívott küzdelemben alkalmazhatók hatékonyan, a küzdő felek fegyverei közötti jelentős méretbeli eltérés azonban másfajta taktikai gondolkodást igényel. Bővebben lásd a távolsággal kapcsolatos taktikai koncepciók leírását. 
hivatkozik a később közölt Jian Jingre: „Pontosan úgy, ahogy a fegyverek dolgait összefoglaló Yu Xujiang ${ }^{12}$ módszere szerint." ${ }^{13}$ Ez a belső hivatkozás is a Jixiao Xinshu víváselméleti szövegei közötti kohéziót erősíti. Mindez valószínüsíti, hogy Qi Jiguang szándéka szerint a Jixiao Xinshuban közölt víváselméleti szövegek együtt egy közös elméleti rendszert alkotnak. Ebböl következően az elemzés során is célszerü egyetlen, többféle vívói szituációra választ kínáló rendszerként kezelnünk a leírtakat.

\section{Értelmezési keretrendszer egy harcmúvészet víváselméleti hátterének a leírásához}

Nem könnyü feladat megtalálni a megfelelö módszert egy történelmi harcmüvészeti rendszer elméleti struktúrájának a leírására. Egy több száz éves, közvetlen élő hagyománnyal nem rendelkező harcmüvészeti rendszer értelmezése és interpretációja önmagában is rengeteg problémát és kérdést vet fel. ${ }^{14}$ Ezen kívül, ahogy Guy Windsor fogalmaz: ,számos történelmi forrás egyáltalán nem tárgyalja az elméletet, csak alapállások és technikák egy listáját tartalmazza. Más források leírják múvészetük elméleti hátterét, de olyan metaforikus vagy kultúrspecifikus ${ }^{15}$ fogalmak használatával, amelyek megnehezítik a szöveg mondanivalójának értelmezését". ${ }^{16}$ A technikai fogalmak jelentésének dekódolását különösen nehézzé teszi, hogy azok általában eredetileg egy szük, zárt közegben alakultak ki, majd az évek során az egyes harcmüvészeti kultúrák fejlődésével számos kulturális réteg rakódott rájuk, amely a mai olvasó számára nem vagy csak részben ismerhető meg. ${ }^{17}$ A Ming-kori katonai harcmüvészeti rendszerek nem rendelkeznek ma élő tradícióval, gyakorlatilag kihalt harcmüvészetnek számítanak, ${ }^{18}$ ezért a kortárs kínai harcmüvészetek ter-

Yu Dayou müvészneve.

必如總戎公命虛江之法 [...] (Qi 1782. 12.juan).

14 A történelmi harcmüvészeti rendszerek kutatása során felmerülő lehetséges problémákról részletesen ld. Burkart 2016.

15 A Ming-kori harcművészetek társadalmi és kulturális kontextusának részletes vizsgálatát ld. Li 2018.

Windsor 2018: 34.

Bauer 2016: 51; 56.

A Ming-kor után a katonai és civil harcmüvészetek teljesen különváltak egymástól. Ezt követően a civil harcmüvészeti kultúra komoly változáson ment keresztül mind eszmeiségét, mind céljait tekintve. Bővebben ld. Lorge 2012: 195. 
minológiáját nem tudjuk segítségül hívni a források értelmezéséhez. ${ }^{19} \mathrm{Ha}$ azonban egy vívórendszer fogalomkészletének értelmezésével boldogulunk is, egy mai szemmel strukturálatlan vagy rosszul strukturált szövegben nem egyszerü meglátni a víváselméleti rendszer egészét, nem könnyü kiválasztani a kulcsfontosságú taktikai elemeket, amelyek a rendszer jellegét meghatározzák Az összetettebb történelmi víváselméleti szövegek értelmezése a kutatótól gyakran nem csupán az elméleti harcművészeti ismereteket követeli meg, de a saját vívói tapasztalatot is. ${ }^{20}$

A legnyilvánvalóbb és legkönnyebben vizualizálható elemek, mint a testtartás, lábmunka, alapállások, a fegyver tartásának módja stb. könnyen felismerhetők, de nem ezek alkotják egy harcmüvészeti rendszer gerincét. Ezek az elemek csak eszközök, amelyek egy vívórendszer megfelelő müködéséhez szükségesek, hogy annak elméleti alapelvei, technikái érvényesülhessenek. Ha szeretnénk átlátni, hogy egy harcmüvészeti rendszer mit határoz meg saját stratégiai céljaként, és azt milyen taktikai eszközökkel éri el, akkor fel kell állítanunk egy olyan értelmezési keretrendszert, amely tartalmazza azokat a taktikai döntéshozatalhoz kapcsolódó csomópontokat, amelyek a közelharci erőszakos összecsapásokra általánosságban véve jellemzők. Ezt követően az adott harcművészet elméleti hátterét e rendszerbe illesztve meg kell vizsgálnunk, hogy ezeken a csomópontokon az elméleti rendszer milyen taktikai döntéseket hoz meg, illetve milyen a csomópontokhoz köthető koncepciók segítségével értelmezi a harci szituációt. Az alábbiakban felsorolt csomópontokat a szerző több történelmi harcmüvészeti rendszer ismerete és személyes harcmủvészeti tapasztalatai alapján jelölte ki. Természetesen lehetségesnek tartjuk víváselméleti rendszerek leírását más pontokra fókuszáló vagy más hangsúlyú ${ }^{21}$ keretrendszer segítségével is, ${ }^{22}$ ugyanakkor úgy véljük, a választott pontok kulcsfontosságúak egy összecsapás során abból a szempontból, hogy a rájuk adott taktikai válaszok összessége jól reprezentálja egy víváselméleti

19 Bauer 2016: 59.

20 Bauer 2016: 54-55.

21 Ren Hong a késői Ming-kori, korai Qing-kori vívórendszereket magyarázó művében az eredeti szövegek struktúráját követve, bekezdésenként elemzi és értelmezi a forrásokat (Ren 2016).

22 Windsor egy hasonló, de bizonyos pontokon eltérő fókuszú keretrendszert javasol a történelmi harcmúvészetek elméleti hátterének a leírására. Az eltérő hangsúlyok oka, hogy jelen munka a vívórendszer elméleti hátterének a leírását tekinti elsődleges céljának, míg Windsor célja a teljes harcmüvészeti rendszer leírása (Windsor 2018: 39-66). 
rendszer egészét. A jelen kutatáshoz készített értelmezési keretrendszer által vizsgált pontok a következők: ${ }^{23}$

- Stratégiai cél: ez a cél lehet az ellenfél minél gyorsabb meggyilkolása, harcképtelenné tétele, küzdősportok esetén pont szerzése stb. A stratégiai cél alapvetően határozza meg egy víváselméleti rendszer taktikai eszközeit és döntéseit. Egy Ming-kori katonai felhasználású harcművészeti rendszer stratégiai célja egyértelmüen az ellenfél minél gyorsabb és hatékonyabb meggyilkolása. Ez a jelen kutatásban vizsgált víváselméleti rendszerre is igaz, hiszen a legtöbb lejegyzett menet szúrással fejeződik be.

- Általános irányelvek: adott rendszer fő fegyvernemének meghatározása, valamint az elvárt vívói tulajdonságok, képességek összessége.

- Távolsággal kapcsolatos taktikai koncepciók: mit tekint az adott rendszer vívói távolságnak? Mely távolság nem képezi még a küzdelem részét? Az elméleti rendszer milyen vívói távolságkategóriákat határoz meg, amelyekre eltérő taktikai válaszokat ad (pl. ütéstávolság, birkózótávolság stb.)? A rendszer taktikai megoldásai szempontjából megkülönbözteti-e az eltérő hosszúságú fegyverekkel vívott, úgynevezett aszimmetrikus vívói helyzeteket a szimmetrikusaktól?

- Idővel kapcsolatos taktikai koncepciók: milyen keret- és fogalomrendszerben értelmezi az adott vívórendszer a vívás idejét, amelyben a vívó felek akciói egymást követik? Az adott rendszer az első- vagy másodszándékból ${ }^{24}$ való vívást propagálja? A kezdeményezést vagy a reakciót?

- Irányokkal kapcsolatos taktikai koncepciók: a vívórendszer által leírt akciók (támadások, hárítások stb.) milyen és hányféle irányok mentén mozognak, hogyan kategorizálja az adott rendszer az akciókat irányuk szerint? Milyen és hányféle célpontot különböztet meg az adott vívórendszer, és ezeket elhelyezkedésük szerint hogyan kategorizálja?

23 A vívói, víváselméleti koncepciók leírásához, magyarázatához a szövegben az európai történelmi harcmüvészet-kutatásban bevett terminológiát használjuk. Ezekhez, ahol szükséges, bővebb magyarázatot is mellékelünk, az értelmezésben azonban további segítséget nyújthat a The Association for Renaissance Martial Arts történelmi harcművészet-kutatással foglalkozó szervezet weblapján található terminológiai szótár: url: http://www.thearma.org/terms2.htm.

24 Elsőszándékú vívás: minden akció célja az ellenfél azonnali megsebzése. Másodszándékú vívás: az első vagy az első néhány akció célja valamilyen reakció kiprovokálása, nem pedig a találatszerzés. 
- Az ellenfél fegyverének kontrollálásával kapcsolatos taktikai koncepciók: az adott vívórendszer propagálja-e a fegyverek kötésbe ${ }^{25}$ kerülését és az abból kivitelezett technikákat? Az adott vívórendszer propagálja-e az ellenfél fegyverének a félreütését? Az adott rendszer propagálja-e az ellenfél fegyverének vagy karjának a megragadását?

- Akciók tipológiája: a támadások és hárítások elnevezései és leírása.

\section{A Jixiao Xinshu víváselméleti rendszerének elemzése}

Az alábbiakban a Jixiao Xinshu víváselméleti koncepcióit a korábban leírt értelmezési keretrendszerbe illesztve vizsgáljuk:

Stratégiai cél: A Jixiao Xinshu víváselméleti rendszere katonai felhasználásra készült, és ez jól látható stratégiai céljában is, amely az ellenfél megölése. Sem a Jian Jing menetei között, sem a Jixiao Xinshu saját víváselméleti értekezéseiben nem találunk kifejezetten az ellenfél lefegyverzését, ártalmatlanná tételét célzó technikákat vagy koncepciókat. Ellenkezőleg: a Jian Jing meneteinek túlnyomó többsége szúrással fejeződik be, ami egyértelmü gyilkolási szándékról árulkodik, és a komplex elméleti koncepciók többsége is a minél tisztábban bevihető szúrásokat teszi lehetővé.

Általános irányelvek: A Qi Jiguang által írt víváselméleti értekezések fő irányelvének az aszimmetrikus harci szituációkra való felkészítést tekinthetjük. A Jixiao Xinshu 10. fejezetét így kezdi:

„A pika elöreszegezésének módja könnyü és régi, [de] ha nem ismerjük a rövid használatának módját, és egy támadásunk nem talál be, vagy betalál, de nem kritikus helyen, az ellenfél a rövid fegyverével közelebb kerül, és nem sikerül időben kihátrálnunk, akkor a hossz hátránnyá válik és [fegyverünk] a puszta kézzel egyenértéküvé [...]."

25 Kötés, lekötés: a két fegyver összeütése során kialakult állapot, amelyben a fegyverek érintkeznek, és keresztezik egymást valamely pontjukon, valamilyen szögben. A legtöbb fegyveres vívórendszerben megtalálhatók az ebből a helyzetből kivitelezett technikák, az állapot elnevezése azonban vívórendszerenként más és más. A kötés, lekötés a középkori német vívórendszerekben használt fogalom (binden), amely talán a legismertebb a fent leírt állapot elnevezései közül. 
長槍架手易老, 若不知短用之法, 一發不中, 或中不在吃緊處, 被他短兵一入, 收退不及, 便為長所誤, 即與赤手同矣 [...] ${ }^{26}$

A 12. fejezet víváselméleti értekezésében pedig a következő olvasható:

„Ha az ellenfél lándzsája 1 zhang 7-8 chi [5-6 m] hosszú, az én fegyverem [hossza] pedig nem haladja meg a 7-8 chit [...] Az ellenfél a pikájával villámgyorsn betör, sebesen, akár a hullócsillag, csak ha nagyon képzett vagyok, tudom megakadályozni, hogy az ellenfél pikája áthatoljon a testemen."

彼之槍一丈七八尺, 我之器不過七八尺[...]彼之長槍閃閃而進, 疾如流星, 我就精熟, 隻能格得彼槍不中入我身耳。27

A Qi által leírt víváselméleti koncepciók gyakorlatilag a Jian Jingben leírtakat egészítik ki az abból a müből hiányzó, speciális harci kontextus, a fegyverek hosszának szempontjából aszimmetrikus vívói helyzetek kezeléséhez szükséges tudással. Ennek megfelelően a leírtakhoz kapcsolódó irányelvek is rendkívül egyszerủek: az aszimmetrikus helyzet különleges megoldásokat kíván, amelyek nélkül nem vagy csak kis eséllyel nyerhetünk a harcban. Minden más szimmetrikus harci helyzettel kapcsolatban Yu Dayou és a Jian Jing tanításai a mérvadóak.

A Jian Jing már a mủ legelején leszögezi, hogy a lejegyzett vívórendszer milyen fegyvernemet használ, és mi az e mögött meghúzódó megfontolás:

„Úgy használd a botot, mintha a Négy Klasszikust olvasnád, a gout, daót, qiangot, bát ${ }^{28}$ mind úgy gyakorold, mint egy-egy írást. Ha a Négy Klasszikus már világos, akkor a Hat Klasszikus lényege is világos. Ha ismered a bot használatát, akkor ebből fakadóan már minden éles fegyver [használatának] módját is ismered."

用棍如讀四書, 鉤刀槍鈀如各習一經, 四書既明, 六經之理亦

明矣。若能棍, 則各利器之法從此得矣。29

Qi 1782: 10. fejezet.

Qi 1782: 12. fejezet.

28 Gou 鉤: kampós végű szálfegyver; dao 刀: egyélü kard; qiang 槍: lándzsa, pika; $b a$ 鈀: háromágú villában végződő szálfegyver.

29

Yu 1782. 
A Jian Jing oktatási filozófiája tehát arra az elvre épül, hogy harcmüvészeti rendszerének elméletét és technikáit a hosszú bot használatán keresztül lehet elsajátítani, de az így megszerzett tudás minden további fegyvernem használata során kamatoztatható.

Víváselméleti koncepcióit tekintve a Jian Jing fó irányelve a szövegben több helyen is olvasható, ám az egyik bekezdésben a szerző maga is egyértelmủen meghatározza:

„A teljes könyv összefoglalása mindössze nyolc írásjegyben [leírható]: használd ki az ellenfél régi erejének elmúltát, mielőtt az új erejét elindítaná. Mily nagyszerü, mily nagyszerü!"

\section{全書總要:隻是乘他舊力略過, 新力未發八字耳。至妙至妙! ${ }^{30}$}

Mindez azt jelenti, hogy a vívórendszer elmélete elsősorban a támadás megfelelö időzítésére épül, és mint az az alábbiakban látható lesz, Yu meglehetősen komplex elméleti struktúrát dolgozott ki ennek a tökéletesen időzített pillanatnak a meghatározására.

Távolsággal kapcsolatos taktikai koncepciók: a Jixiao Xinshu a fegyverek hossza alapján különbözteti meg az eltérö taktikai döntéseket igénylő távolságokat. Eszerint, ahogy arról már korábban szó volt, megkülönböztet szimmetrikus és aszimmetrikus vívói helyzeteket, de csak az aszimmetrikus szituációkkal foglalkozik. Ezeket két kategóriába sorolja: a hosszú fegyverek rövid használata - vagyis amikor egy hosszú fegyvert használva nézünk szembe egy rövid fegyvert forgató ellenféllel; és a rövid fegyverek hosszú használata - amely helyzet esetén a mi fegyverünk esik a rövid kategóriába, ellenfelünknél pedig hosszú fegyver van. A szöveg besorolása szerint hosszú fegyvernek minősülnek a 8 chinél 尺 (kb. $21 / 3$ méter; 1 chi $=1 / 3$ méter $^{31}$ ) hosszabb fegyverek. Ilyenek a különféle, alakzatharcban használatos pikák. Rövid fegyvernek minősülnek a 8 chinél rövidebbek. Eszerint rövid fegyver minden olyan szálfegyver, amely ebbe a hosszkategóriába esik, valamint a kard is. Qi megjegyzi, hogy az oldalkard (yaodao 腰刀) és pajzs kombinációja ,a rövid fegyverek között is rövidnek számít, ezért ezek mellett kötelező a hajítódárda használata" ${ }^{32}$ Kardnál rövidebb fegyverekről, például késről, tőrről nem esik szó.

\footnotetext{
30 Uo.

31 Twitchett-Fairbank 2008: xxi.

32 ,本短中之短也而必用標槍” (Qi 1782: 12. fejezet)
} 
A Jian Jing nem helyez hangsúlyt a különböző távolságok kategorizálására, nem alkalmaz a hagyományos vívótávolságnál közelebbről használható birkózótechnikákat. Egyedül a vívó- és a víváson kívüli távolságot ismeri a rendszer, ám ezt sem jelzi explicit módon, csupán a vívótávolságból való kivonulást leíró technikákban jelenik meg a különbség.

Qi Jiguang a hosszú fegyverek rövid használatát leíró értekezésben a következő instrukciókat adja:

„A pika elöreszegezésének módja könnyü és régi, [de] ha nem ismerjük a rövid használatának módját, és egy támadásunk nem talál be, vagy betalál, de nem kritikus helyen, az ellenfél a rövid fegyverével közelebb kerül, és nem sikerül időben kihátrálnunk, akkor a hossz hátránnyá válik, és [fegyverünk] a puszta kézzel egyenértéküvé [...]."

\section{長槍架手易老, 若不知短用之法, 一發不中, 或中不在吃緊處, 被他短兵一入, 收退不及, 便為長所誤, 即與赤手同矣[...]。33}

„Az ellenfél fegyvere nem kerülhet kötésbe az én lándzsám belső oldalával, és akkor ebből következően az ellenfél biztosan nem mer könnyedén közel jönni. A kezemben tartott pika húzódjon vissza bö 1 chi távolságra, hogy még le tudjam vele szúrni a másikat, ugyanúgy, mintha rövid fegyvert használnék. Ez a hosszú [fegyverek] rövid használatának titka."

\section{彼器不得交在我槍身內, 彼自不敢輕進 ; 我手中槍就退至一尺 餘, 尚可翟人, 與短兵功用同矣, 此用長以短之秘也。34}

Hosszú fegyverrel való aszimmetrikus küzdelem esetén tehát a fö cél az ellenfél közelkerülésének a megakadályozása, valamint ha ez mégsem sikerülne, a hosszú fegyver visszahúzása és rövid fegyverként való használata.

A rövid fegyverek hosszú használatáról szóló értekezés lényegét a következő részletek tükrözik:

„Tudniillik a kezünkben tartott chai, gun, gou vagy ba 6-7 chinél hoszszabb, és az ellenfél hosszú [támadással] közelít felém, biztosan hatoljak elöre 5 chinyit, védjem magam kifelé irányuló ütések sorozatával, vagyis »a rúd folyamatos belső ütése« technikát alkalmazzam [...]."

33 Qi 1782: 10. fejezet.

34 Uo. 
則所執釷棍鉤鈀皆有六七尺在外，彼若以長入我，必須進深五 尺，被我一格打歪，即用棍內連打之法[...]。35

„Először be kell hatolnom a hosszú fegyver [hatókörén] belülre, és csak azután mozoghat a rövid fegyverem szabadon, és [válik] a hosszú fegyver a puszta kézzel egyenértékűvé."

一入長兵之內, 則惟我短兵縱橫, 長兵如赤手同矣。36

„A rövid fegyverek előnye a gyors előretörésben és annak kihasználásában rejlik, hogy a hegyüket nehéz lekötni, mégis hosszan elöreállnak.”

短兵利在速進, 終難接長持久, 即為所乘。37

Mint ahogy az a fenti idézetekből kitünik, rövid fegyvert alkalmazó aszimmetrikus harci szituáció esetén a Jixiao Xinshu a hosszú fegyver félreütését és a hatókörén belülre való gyors betörést tanítja. Megvizsgálva a szöveg által tárgyalt két különböző aszimmetrikus helyzetre adott válaszokat, tisztán látszik, hogy azok pontosan egymás ellentétei: a taktikai célkitűzések mindkét esetben a másik fegyver hosszából fakadó hátrányok kihasználását, a saját fegyver gyengeségeinek az ellensúlyozását célozzák. Ebből is látható, hogy jól átgondolt, a fegyverek tulajdonságaira nagy hangsúlyt fektető elméleti rendszerrel van dolgunk.

Idővel kapcsolatos taktikai koncepciók: a víváselméleti rendszer egyik legfontosabb idővel kapcsolatos jellemzője a másodszándékú vívás. A másodszándékú vívás lényege, hogy a támadások célja nem az azonnali, biztos találat bevitele, hanem az ellenfél valamilyen reakciójának a kikényszerítése különböző akciókkal, támadásokkal, cselekkel, provokációkkal - ezt nevezzük elővívásnak -, amely reakciót kihasználva azután kivitelezhetők a rendszer technikái. A másodszándékú vívás fontosságát a szöveg több helyen is hangsúlyozza:

„Aki másodszor üt, annak győzelme előbb érik be.”

後發勝先實 ${ }^{38}$

Qi 1782: 12. fejezet.
Uo.
Uo.
Yu 1782. 
„Tudd meg, sohasem lehet egyetlen támadással azonnal megsebezni valakit $[\ldots]$."

知此, 決不可一發便要傷人 $[. .$.$] 。 { }^{39}$

Továbbá:

„Ne az első alkalommal üsd meg az ellenfelet, csakis a második alkalommal üsd meg öt."

不打他先一下，隻是打他第二一下。 ${ }^{40}$

Yu Dayou víváselméleti rendszerének legfontosabb koncepciója szintén a vívás idejével kapcsolatos. A rendszer a vívásra akciók sorozataként tekint, amelyek egymást követően reakciókat és ellenreakciókat váltanak ki a vívó felekből. Az akciókat a rendszer zhuannak 轉 nevezi, ám nem ezek, hanem a zhuanok egymáshoz viszonyított időbeli sorrendje állnak a Jian Jing víváselméletének a fókuszában. Más szóval a megfelelö zhuan megválasztását célzó taktikai döntés azon alapul, hogy egy akció megelöz vagy követ-e egy másikat. A rendszer logikája szerint akciónk jellegét attól függően kell megválasztanunk, hogy az az ellenfél cselekedetét megelőzi vagy követi. Ezzel kapcsolatban így ír a forrás:

„Keményen a másik ereje elött, lágyan kihasználni a másik ereje után.

Ha az ellenfelem elfoglalt, én nyugodtan várok [...].”

剛在他力前, 柔乘他力後。彼忙我靜待, [...]。41

Mindez azt jelenti, hogy ha a kezdeményezés az enyém, és én indítok egy akciót, az erőteljes és agresszív kell, hogy legyen, az ellenfelet reakcióra kell kényszerítenie, mert ha az nem reagál, a támadásom megsebzi. Ezzel szemben, ha az ellenfél kezdeményezett, akkor felesleges azonos erővel reagálnom az ő domináns akciójára, ehelyett valamilyen technika alkalmazásával vissza kell szereznem a kezdeményezést, a saját akcióját ellene fordítva.

A Jian Jing víváselméletének legmagasabb szintü koncepciója azonban a fenti két kategória egyikébe sem esik, hanem az ellenfél akciójával azonos zhuanban indított akcióval szerzi vissza a kezdeményezést, és kényszeríti

\begin{tabular}{ll}
\hline 39 & Uo. \\
40 & Uo. \\
41 & Uo.
\end{tabular}


az ellenfelet reakcióra. Az ilyen típusú akciót a rendszer dangnak 當 nevezi, amely jelen kontextusban leginkább ,a megfelelő pillanat”, ,megfelelő időzítés" jelentéssel rendelkezik. A dang lényege, hogy egyetlen akcióként akasztja meg az ellenfél támadását, hárítja azt, és támad vissza. A sikeresen kivitelezett dang a Jian Jing vívórendszerében a vívás csúcsát jelenti. Ahhoz, hogy a dang sikeres legyen, az ellenfél akciójának megfelelő szakaszában kell kivitelezni. Ezt a szakaszt a rendszer paiweinek 拍位 ( $\mathrm{kb}$. az ütem helye) nevezi. A paiwei eltalálása feltétele a dang kivitelezésének. A szöveg így ír:

„Ez a dang írásjegy olyan, akár a dalokban az ütem helye, elmondhatatlanul csodálatos."

此當字如曲中之拍位, 妙不可言, [...]。 ${ }^{42}$

Valamint:

„Az úr az ütem szerepét ismerve harcol.”

知拍任君鬥。43

A szerző a dang nehezen magyarázható, elvont koncepciójának megértését három egyszerü diagramma ${ }^{44}$ igyekezett segíteni, ezek a következők:

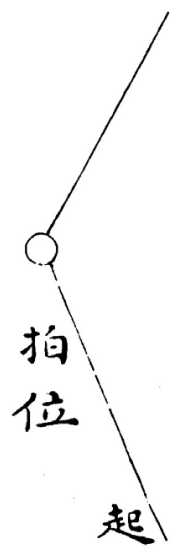

1. diagram: a qi 起 írásjegy az ellenfél akciójának a kezdetét jelöli, a paiwei időpontja ezt követően, de még az akció befejezése elött található

$42 \quad \mathrm{Yu} 1782$.

43 Uo.

44 A diagramok forrása: Yu 1782. 


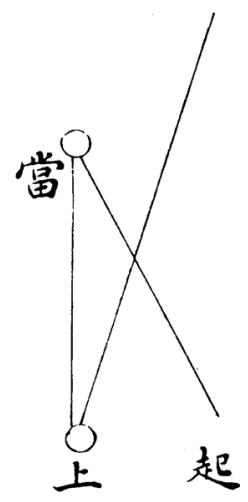

2. diagram: a qi 起 írásjegy az ellenfél akciójának a kezdetét jelöli, a dang ezt követöen valósitható meg. A shang 上 írásjegy a dangba foglalt támadás fölsö (felülröl ereszkedö) irányát jelöli

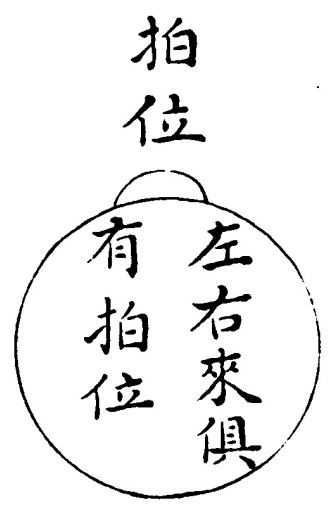

3. diagram: a képen a következő szöveg olvasható: „, a balról és jobbról jövő [támadások esetén] egyaránt van paiwei”. A „, balról és jobbról jövö” az ellenfél támadásának lehetséges irányaira utal, amelyek ellen egyaránt alkalmazható a dang, mert megtalálható bennük a paiwei pillanata. Feltehetöen az ábra tetején látható kisebb félkör jelzi a paiwei szük időablakát az ellenfél akcióját jelképezö nagyobb körhöz viszonyítva

Irányokkal kapcsolatos taktikai koncepciók: a Jian Jing víváselméleti rendszere célpontok tekintetében két fö területet különböztet meg az ellenfél testén: a nagy kaput (da men 大門) és a kis kaput (xiao men 小門). A nagy kapu a törzs derékon felüli részét és a fejet jelenti, a kis kapu az ágyékot és a lábakat. A támadások túlnyomó többségének célpontja a nagy kapu. A szöveg a vívómenetek leírásánál ugyanezt a terminológiát használja arra, hogy leírja bizonyos szituációkban a fegyverek helyét, attól függően, hogy azok az alsó vagy 
a felső célpontra mutatnak éppen. További, ritkább célpont a kéz, föleg a lekötésből kivitelezett $t i$ 剃 és gun 滾 támadástípusok esetén. Fontos megjegyezni, hogy a víváselméleti rendszer másodszándékú vívási jellegéből fakadóan gyakori első célpont az ellenfél fegyvere, ez azonban soha nem a támadások valódi célpontja.

Az akciók lehetséges irányait tekintve a rendszer megkülönböztet fentröl lefelé irányuló ütéseket ( $d a$ 打), lentről felfelé irányuló ütéseket (jie 揭), egyenes ütéseket (zhipo 直破) és szúrásokat ( $s h a$ 殺). A rendszer propagálja a hatékonyabbnak tartott egyenes támadásokat a lentről vagy fentről indított, harántirányúakkal szemben.

\section{Az ellenfél fegyverének kontrollálásával kapcsolatos taktikai koncep-} ciók: a vívórendszer másodszándékú jellegéből fakadóan gyakoriak az ellenfél fegyverének félreütését célzó akciók. Az ilyen akciók célja mindig valamiféle kívánt reakció kikényszerítése az ellenfélből, ezáltal utat nyitva egy valódi, a testet célzó támadásnak.

A rendszer előszeretettel alkalmazza a lekötéseket is. A fentebb, az idővel kapcsolatos koncepciók között említett dang megfelelő alkalmazása esetén is gyakori, hogy lekötés következik be, amelyet a vívó a maga előnyére fordíthat. A lekötést a rendszer ollónak (jian 剪) nevezi (feltehetően a két fegyver által formált ollószerü forma után), és megkülönbözteti kicsi (xiao jian 小剪) és nagy (da jian 大剪) változatát. Kicsi olló esetén a fegyverek a hegyükhöz közelebb találkoznak, nagy olló esetén pedig a vívók kezéhez közelebb. Az ollóból kivitelezett leggyakoribb akció az egyenes szúrás, ezt azonban megelőzheti az ellenfél fegyverén végigcsúsztatott ütés, amelynek gyakori célpontja a fegyvert markoló kéz. Ennek a támadástípusnak az alulról felfelé irányuló változatát gunnak 滾, fentről lefelé irányuló változatát pedig tinek 剃 nevezzük. A rendszer a legtökéletesebb támadásnak azt tekinti, ha az ellenfél mozdulatába a paiwei elmélete szerinti megfelelő pillanatban egyenesen beleütve, a lekötésből irányuló egyetlen sima mozdulattal szúrunk:

„Ha középen létrejön a paiwei, nem emeljük le [fegyverünket az ellenféléről], nem alkalmazunk tit vagy félreütést, csak kezünket elörelendítve szúrunk, és mindezt igen szük [mozdulattal]."

中間有拍位, 不用拔剃洗落, 隻撒手殺, 則又緊矣。 45

45 Yu 1782. 


\section{Akciók tipológiája:}

- $D a$ 打: fentről lefelé irányuló harántütés

- Jie 揭: lentről felfelé irányuló harántütés

- Zhipo 直破: függőleges ütés

- Sha 殺: szúrás

- Gun 㳘: lekötésből az ellenfél fegyverén végigcsúsztatott, alulról induló ütés

- $T i$ 剃: lekötésből az ellenfél fegyverén végigcsúsztatott, felülről induló ütés

- Dang 當: a paiwei pillanatában kivitelezett ütés, amely megakasztja az ellenfél fegyverét

- Hong 哄: csel, hamis akció az ellenfél megtévesztésére

- Gou 勾: provokáció, szándékosan nem védett nyílás

Az akciók tipológiája jól mutatja, hogy a különféle támadástípusok a fent említett összes lehetséges célpont fenyegetését lehetővé teszik, különböző irányokból. A gun és a ti a fegyverek kötésbe kerülését használják ki. A hong és a gou tipikusan a másodszándékú vívórendszerekre jellemző akciótípusok.

\section{Összefoglalás és a kutatás jelentősége}

A fentieket figyelembe véve egyértelmúen látható, hogy a Jixiao Xinshu víváselméleti rendszere, a Jian Jing adoptálásával egy rendkívül komplex vívórendszer, amely a katonai igényeket maximálisan képes volt kielégíteni. Magába foglalja a kezdők kiképzéséhez szükséges alapvető ismereteket, de mély és komplex elméleti hátteret biztosít a tapasztalt vívók képzéséhez is. A rendszer két legfőbb fókusza a vívás idejének taktikus szemlélete, valamint a távolság taktikai kihasználása a fegyverek eltérö hosszából fakadó aszimmetrikus harci szituációkban. A vívás idejével kapcsolatos taktikai koncepciókat a Jian Jing írja le. Ezek közül a legfontosabbak a másodszándékú vívói szemlélet és a támadás az ellenfél akciójához viszonyított tökéletes időzítése. A távolsággal kapcsolatos taktikai koncepciók a Jixiao Xinshu eredeti szövegének a részét képezik. Tartalmuk lényege, hogy rövid fegyverrel hosszabb fegyver ellen harcolva fontos minél gyorsabban a hosszú fegyver effektív hatókörén belülre kerülni, ahol az már nem használható hatékonyan; hosszú fegyverrel pedig mindenáron távol kell tartani a rövidebb fegyverrel harcoló ellenfelet.

Érdekességképpen megemlíthető, hogy a Jixiao Xinshu víváselméleti rendszerének másodszándékú vívói szemlélete, valamint a vívás idejének akciókra való felosztása jelentős hasonlóságot mutat a XVI. századi itáliai vívómester, 
Achille Marozzo (1484-1553) tempóelméletében megfogalmazott időszemlélettel. ${ }^{46}$ Ezenkívül a dang koncepciója, nevezetesen hogy egyetlen akcióként hárítja az ellenfél támadását, és támad vissza, lényegében megegyezik a XIV. századi német vívómester, Johannes Liechtenauer ${ }^{47}$ absetzen nevủ technikájával. ${ }^{48} \mathrm{~A}$ hasonlóságok természetesen nem jelentenek semmiféle kapcsolatot az európai és a kínai történelmi vívórendszerek között, viszont jól mutatják, hogy időtől, kultúrától és földrajzi elhelyezkedéstől függetlenül hasonló tulajdonságú fegyverek használata csak hasonló, véges számú variációjú taktikai megfontolás szerint müködhetett hatékonyan.

A Jixiao Xinshu víváselméleti rendszerének itt közölt, strukturált leírása harcmüvészet-történeti és kultúrtörténeti forrásként önmagában is érdeklődésre tarthat számot. Segítségével megismerhetjük, hogy a Ming-kor művelt és tapasztalt katonatisztjei milyen absztrakt koncepciók segítségével értelmezték és próbálták megzabolázni azt a kaotikus jelenséget, amelyet erőszakos fegyveres összecsapásnak nevezünk. Nem szabad azonban megfeledkeznünk a Qi Jiguang által lejegyzett víváselméleti rendszer hadtörténeti jelentőségéről sem. Ismert történelmi tény, ${ }^{49}$ hogy Qi különlegesen kiképzett hadserege kulcsszerepet töltött be a wokou kalózok leverésében az 1550-es, 60-as években. Az ekkor alkalmazott kiképzési módszerek jelentős részét a tábornok később a Jixiao Xinshuban jegyezte le. Qi Mingshiben található életrajza tartalmaz egy részletet, amely arra enged következtetni, hogy a fent bemutatott víváselméleti rendszer is részben vagy egészében a kiképzés részét képezte:

„Amikor Jiguang Zhejiangba érkezett, látta, hogy a reguláris hadsereg gyakorlatlan a hadviselésben [...] kérvényezte háromezer fő toborzását, és megtanította nekik az ütés és szúrás módját, a hosszú és rövid fegyverek használatát [...]."

繼光至浙時, 見衛所軍不習戰, [‥]請召募三千人，教以擊刺法 , 長短兵迭用, $[\cdots]$ 。 50

A „hosszú és rövid fegyverek használatának” említése valószínüsíti, hogy Qi már ekkor a Jixiao Xinshuban leírtakhoz hasonló víváselméleti koncepciókat

\footnotetext{
Marozzo 1536.

Liechtenauer születésének és halálának pontos dátuma ismeretlen.

Anonymous 1389.

Twitchett-Fairbank 2008: 503.

Zhang 1739.
} 
tanított katonáinak. Amennyiben ez a következtetésünk helyes, az azt jelenti, hogy Qi víváselméleti rendszerének megismerésével rendkívül részletes képet kapunk arról, hogyan is harcoltak a tábornok katonái. Ennek révén pedig egy lépéssel közelebb kerülhetünk annak megértéséhez, hogy pontosan milyen új tényezők tették lehetővé Qi serege számára a wokou kalózok legyőzését más Ming hadvezérek korábbi kudarcait követően.

Végezetül felhívnám a figyelmet arra, hogy a Jixiao Xinshu víváselméletének strukturált leírásához használt értelmezési keretrendszer további jövőbeli, történelmi vívórendszerek leírását célzó kutatásokban is felhasználható. Ebben a minőségében jelen munka hozzájárulhat a harcmüvészet-kutatás viszonylag fiatal, de dinamikusan növekvő tudományterületének ${ }^{51}$ további fejlődéséhez.

A kutatás az Emberi Erőforrások Minisztériuma ÚNKP-18-3 kódszámú Új Nemzeti Kiválóság Programjának támogatásával készült.

\section{Elsődleges források}

Qi, Jiguang 戚繼光 1782. Jixiao xinshu 紀效新書 [Új értekezés a katonai hatékonyságról]. (SKQS ed.)

Yu, Dayou 俞大猷 1782. ,Jian Jing 劍經 [Értekezés a kardról]” In: Qi Jiguang 戚繼光. Jixiao Xinshu 紀效新書 [Új értekezés a katonai hatékonyságról]. (SKQS ed.)

Zhang, Tingyu 張廷玉 (ed.) 1739. Ming Shi 明史 [A Ming-dinasztia krónikája] (forrás: Wikisource url: https://zh.wikisource.org/wiki/\%E6\%98\%8E\%E5\%8F\%B2 utolsó megtekintés: 2019. 06. 23.).

\section{Felhasznált másodlagos szakirodalom}

Anonymous ca. 1389. M53. Cod. Hs. 3227a. [Nürnberger Handschrift, Codex Döbringer]. Bauer, Matthias Johannes 2016. „Teaching How to Fight with Encrypted Words: Linguistic Aspects of German Fencing and Wrestling Treatises of the Middle Ages and Early Modern Times". In: Jaquet, Daniel - Verelst, Karin - Dawson, Timothy (eds.) Late Medieval and Early Modern Fight Books: Transmission and Tradition of Martial Arts in Europe (14th-17th Centuries). Leiden-Boston: Brill, 47-61.

Bowman, Paul 2015. „Asking the Question: Is Martial Arts Studies an Academic Field?”. Martial Arts Studies 1: 3-19.

Burkart, Eric 2016. „Limits of Understanding in the Study of Lost Martial Arts”. Acta Periodica Duellatorum 4/2: 5-30.

51 Bowman 2015. 
Clements, John 2016. „Problems of Interpretation and Application in Fight Book Studies”. In: Jaquet, Daniel - Verelst, Karin - Dawson, Timothy (eds.) Late Medieval and Early Modern Fight Books: Transmission and Tradition of Martial Arts in Europe (14th-17th Centuries). Leiden-Boston: Brill, 189-215.

Guo, Elisabeth - Kennedy, Brian 2005. Chinese Martial Arts Training Manuals; A Historical Survey. Berkeley, California: Blue Snake Books.

Li, Jiyuan 李吉远 2018. Mingdai Wushushi Yanjiu 明代武术史研究 [A Ming-kori harcmüvészet-történet vizsgálata]. Zhongguo Shehui Kexue Chubanshe 中国社会科学出版社.

Lorge, Peter 2012. Chinese Martial Arts: from antiquity to the twenty-first century. New York: Cambridge University Press.

Marozzo, Achille 1536. Opera Nova. (Wilson, William trans.) Modena: D. Antonio Bergolae. (Forrás: Wiktenauer. url: https://wiktenauer.com/wiki/Achille_Marozzo. utolsó megtekintés: 2019. 06. 23.)

Ren, Hong 任鸿 2016. Shoubilu, Wuyinlu Shiyi - Mingdai Qiangfa Duanbing Jiemi 手臂录·无隐录释义：明代枪法短兵解密 [A Shoubilu és a Wuyinlu interpretációja - a Ming-kori lándzsavívás és rövidfegyverek titkainak megfejtése]. Shanxi Kexue Jishu Chubanshe 山西科学技术出版社.

The Association for Renaissance Martial Arts Definitions \& Study Terminology. http://www.thearma.org/terms2.htm (utolsó megtekintés: 2019. 06. 23.).

Twitchett - Fairbank (eds.) 2008. The Ming Dynasty, 1368-1644, Part I. [The Cambridge History of China 7.] New York: Cambridge University Press.

Windsor, Guy 2018. The Theory and Practice of Historical Martial Arts. Spada Press. 